Lotta JalaVA (Helsinki)

\title{
“Adjectives" in Tundra Nenets: Properties of Property Words
}

\begin{abstract}
Nenets expresses property with lexical items that represent two main word classes: nouns and verbs. This study focuses on the morphological and syntactic features that are typical to adjectives in other languages and also characteristic to property words in Nenets: attributive and predicative positions, derivation, comparative construction and the formation of adverbs of manner. It argues that Nenets property words have features that distinguish them from other nouns and verbs. Furthermore, the study aims at explaining the dichotomy of Nenets property words in two words classes. At the same time, the study takes part in the discussion of the cross-linguistic universality of adjectives and linguistic categorization.
\end{abstract}

\section{Introduction}

Criteria on how to define adjectives vary from one language to another and depend on the approach and definition of word classes. Moreover, features and the morphosyntactic behaviour of describing property words, that is, adjectives, vary prominently from one language to another. (Dixon 1977: 2004.) In some languages, adjectives are similar to nouns, as in Finnish, where they are inflected in number and case. In some languages, such as Korean, they resemble verbs in their syntactic behaviour (Sohn 2004). Depending on the language and criteria for classification, adjectives can be considered to form a category in its own right or a subcategory of nouns or verbs. For instance, adjectives in Finnish are usually considered to be a subclass of nouns (VISK $\S 603$ ), or a word class in its own right (Pajunen 1994). However, in some languages, like in Northern Iroquoian, it seems to be impossible to differentiate an adjective class from nouns or verbs by any criteria (Chafe 2012). Thus, the universality of adjectives as a word class has been questioned for good reason. However, all languages somehow lexically express properties, and with careful analysis, adjectives can in most, if not all, languages be distinguished from nouns and verbs by languageinternal criteria (Dixon 2004).

One of the languages, in which the existence of adjectives as a word class has been questioned, is Nenets, which, at least by strictly morphological criteria, lacks one consistent category of adjectives (Tereščenko 1956, Hajdú 1968, Salminen 1993). In order to express properties that other languages with a more clear and uniform adjective class expressed with adjectives, Nenets uses words from the two major word classes: nouns or verbs, e.g. pirća 'high, tall' is considered a noun and téćz(s') V '(be) cold' is a stative verb. The two types of property concept words do not share such morphological features that would differentiate them from nouns and verbs, whereas for example in Finnish, comparative and superlative forms are typical to adjectives and adverbs of manner but only in limited use with nouns. 
The focus of the present study are those Nenets words that possess the following syntactic and semantic features typical to adjectives from a typological perspective (Dixon 2004: 14). I use the term property concept word for words that apply to these functional, semantic and syntactic definitions, a term used by Thompson (1988: 167) for "those concepts referring to properties, qualities or characteristics of referents". As for the adjective, I use this term for members of a word class or category sharing grammatical features that distinguish them from other word classes or categories. By this definition, Nenets property words can:

a) modify the head in a noun phrase

narka poyka 'a big net'

big.SG net.SG

b) function as an intransitive predicate

poyka narka $(-\varnothing)$ 'the net is big'

net.SG big.3sG

c) belong to one of the seven typical adjectival semantic types (Dixon 1977; 2004: 14)

dimension ('́ud'a 'small', yarka 'big');

age ('́ewxi 'old, ancient', jedej 'new');

value (sawa 'good', woewa 'bad');

colour (parid'e(s') '(be) black', ser 'white');

speed (meréc' '(be) fast')

physical property (téćz(ś) '(be) cold', śíbić 'light'), and

human propensity (śadoć '(be) beautiful', jíbeć '(be) clever').

Thus, ṕirća N 'high, tall' and téćs(ś) V '(be) cold' are both property concept words, but as they belong to different major word classes, they cannot be called adjectives in the sense of one grammatically uniform category.

The fact that Nenets property concept words represent two different word classes, has been known since Castrén's grammatical description of the Samoyedic languages, in which he takes note of a group of adjectives that, unlike others, require a specific suffix when acting in an attributive position (1854: 186-187). In her basic grammatical descriptions of Nenets, Tereščenko $(1947,1965)$ uses the term adjective for property words, giving examples of both verb and noun forms in an attributive position and mainly describing property nouns in a predicate position. In Tereščenko's other publications, including materials and studies on Nenets (1956) and a paper on the parts of speech in the Samoyedic languages (1968), the nature and form of property concept words in Nenets is explained in more detail. In her closer analysis, Tereščenko (1956) uses the term "expressions of quality" for words called property words in this study. Later descriptions of Nenets (Hajdú 1968; Salminen, 1993, 1997) point out its lack of adjectives by morphological criteria. However, Salminen (1993: 257-261) recognizes an adjective subclass of nouns that can be differentiated "on the basis of derivational and syntactical peculiarities". 
In the present study, these characteristics of both property nouns and property verbs will be discussed in more detail. I follow Salminen's (1993) morphological definitions of Nenets major word classes, on basis of which property concept words are divided into two different word classes. My presumption is that despite the fact that property words belong to two different main word classes, they share some features typical to adjectives from a typological perspective, in which they differ from other nouns and verbs, even if the difference cannot be defined by clear morphological or syntactical criteria. I will argue that certain constructions and structures are formed only with the help of property words, but not other nouns and verbs.

The research questions in this study are:

1) What are the morphosyntactic characteristics of property concept words?

2) What is the distribution of representatives of different semantic adjectival types in the two lexical categories?

2) What are the functional characteristics of property concept words?

4) Do property concept words form subclasses of nouns and verbs?

In Section 2, I will give the background to linguistic categorization and the division of word classes in general, and especially to adjective classes, both in typology and from the perspective of the Uralic languages. Section 3 gives an overview of the main word classes in Nenets, and Section 4 introduces the syntactic structure of verbal and nominal property concept words in attributive and predicative positions, giving a perspective on the first research question. In Section 5, I will discuss the lexical categorization of the property words. I will look at the distribution of nominal and verbal property concept words in prototypical adjectival semantic types in order to explain the development of the dichotomy of property concept words. In Section 6, I will investigate syntactic and derivational features of the words under examination in order to answer the third research question. Section 6.1 discusses certain derivational suffixes that either produce property words or change or specify their meaning, 6.2 discusses comparative construction, and 6.3 discusses adverbs of manner. Finally, in Section 7, I will draw conclusions about the classification of property concept words and the definition of adjectives in Nenets.

In this study, Nenets shall refer to the language of Tundra Nenets, the more extensively studied and widely spoken language variety of the group of the Nenets languages, from which the data is drawn. This is why the results cannot necessarily be applied to the other Nenets language, Forest Nenets, the closest related language to Tundra Nenets. The data consist of published grammars and previous studies of the Nenets language (Tereščenko 1947, 1956, 1965; Salminen 1993, 1997) as well as my fieldwork recordings from the Taimyr Peninsula (NenTay2011) ${ }^{1}$, including personal

1. The fieldwork was conducted together with Dr. Florian Siegl to whom I am extremely grateful for all his guidance and support. 
and traditional stories in Nenets, elicited translation sentences and interviews on the basis of questionnaires, recorded in autumn 2011. The example sentences presented in the study derive from the fieldwork materials (NenTay2011), and they are complemented with examples from Tereščenko's $(1965=$ T65) extensive Nenets-Russian dictionary and also her book of Nenets language materials (Tereščenko $1956=\mathrm{T} 56$ ). The Nenets examples will be given in transcription based roughly on the Uralic Phonetic Alphabet (UPA), but the principles of the transcription used here are phonological instead of phonetic. Hence, the marking follows the transcription system used at present for other Uralic languages, such as Mordvin, instead of Cyrillic orthography. The transcription used excludes the marking of the schwa phoneme (Salminen 1997: 31-32) in unstressed positions, but should be accurate and clear enough for purposes of syntactic research.

\section{Property concepts and word classes}

\section{I. Word classes}

Lexical categorization in languages is often based on the prototypical meaning and form of verbs and nouns. In the languages of the world, unmarked verbs typically refer to actions, and they are used as head of predicate. Unmarked nouns typically refer to concrete objects and fulfil the function of reference, occurring in an NP which is the argument for a predicate. Unmarked adjectives typically refer to properties and are used in a modifying function. However, verb forms in many languages appear in an NP, and in some languages nouns and/or adjectives are used as a predicate. (Croft 1991: 67; 2001: 88; Dixon 2010: 39.) Atypical syntactic uses of lexical items have made linguists doubt the distinction of main word classes in individual languages and also cross-linguistically. For example there have traditionally been claims that Mundari, an Austroasiatic language of India, lacks word classes because a single word can function in the position of a noun, verb or adjective according to context (Evans \& Osada 2005).

Most of the languages of which the distinction of word classes has been questioned are found in the modern non-European language groups, but the same question has also been raised about Proto-Uralic, the early predecessor of Nenets; also because of non-prototypical use of lexical items (for example Ravila 1957). The division of verbs and nouns has been questioned i.e. by Ravila (1957) mainly based on the following features of Proto-Uralic: 1) many inflectional and derivational suffixes could have been affixed to both nominal and verbal stems (Janhunen 1998: 28), 2) a group of roots, such words as *tuule- 'wind', seem to have been morphosyntactically used either as nouns or verbs (ibid.), 2) a large number of nominalized Proto-Uralic verb forms have been reconstructed (Janhunen 1981: 33-34), and 4) nouns were able to take the predicate position of the clause and were conjugated as verbs (Bartens 1981: 101). More recent studies have pointed out that the division between nouns 
and verbs in Proto-Uralic can be made on the basis of morphological and syntactic criteria (Bartens 1981: 101, Janhunen 1981: 28, Pajunen 1998). The tendency to distinguish word classes in Proto-Uralic on the basis of careful distributional analysis within Finno-Ugric studies goes hand in hand with the same tendency in typological research and studies of individual languages based on a typological approach. A closer distributional analysis of Mundari, which has been claimed to lack word classes, also shows that distinct open classes of verbs and nouns as well as a closed class of adjectives can be distinguished in the language (Evans \& Osada 2005).

It has been argued that all languages make a distinction between nouns and verbs (Dixon 2010: 37-38, Schachter \& Shopen 2007: 13). However, there are languages, such as Tongan, a Polynesian language, in which lexical categories can be distinguished, but the criteria for division are not based on the features typologically most characteristic to nouns and verbs (Broschart 1997). Thus, it seems that by careful analysis, at least two main word classes can be distinguished in all languages, but the properties of nouns and verbs are not the same in different languages, although they often follow prototypical semantic and syntactic features. Consequently, the distinguishing criteria are language-specific. Different terminology is needed for language-specific description and for cross-linguistic comparison (see e.g. Ravila 1957: 44, Haspelmath 2010), sometimes also for word classes such as adjectives $\sim$ property concept words.

\subsection{Property concept words and adjectives}

In recent decades, the cross-linguistic universality of the category of adjective has been discussed in both typology and in studies concentrating on individual languages. (Dixon 1977, 2004; Wierzbicka 1986; Evans \& Osaka 2005; Chafe 2012). The studies show that all languages can express properties and fulfil semantic and syntactic roles typical to adjectives by some means, and that it is characteristic of adjectives that they express property-like qualities, features and similarities. However, the features and morphological and syntactic behaviour of members of a class of adjectives (or property concept words without a consistent category) prominently vary from one language to another, and it has been stated that even if all languages seem to distinguish nouns and verbs, only some languages distinct adjectives from verbs and nouns (Schachter \& Shopen 2007: 13). Also, the size of inventory of adjectives varies from language to another, from only a few members of a closed class to an unlimited number in an open adjective class, which can productively take new members (Dixon 1977, 2004; Wierzbicka 1986).

In his widely known paper "Where have all the adjectives gone?", Dixon (1977) took an approach to explore the existence and substance of major word classes in different languages. He noticed that all languages do not have adjective classes at all, and in some languages, the size of the class of adjectives can vary from only a few words to an unlimited number. More recently, Dixon (2004) corrects his earlier view (1977), 
arguing that all languages have a distinguishable class of adjectives just like they have word classes for verbs and nouns. He suggests that adjective classes should be distinguished from nouns and verbs of a given language by language-internal criteria. Recently, adjective classes have indeed also been discovered or defined in languages where the occurrence of adjectives has earlier been dubious, such as Inuit with two adjective classes (Compton 2012), Mundari with a closed class of adjectives (Evans \& Osada 2005), and Quechua with a distinct class of attributive modifiers (Floyd 2011). At the same time, it has been suggested that even after careful examination, the category of adjectives in some languages, such as the Northern Iroquoian languages of eastern North America (Chafe 2012), cannot really be distinguished by any criteria.

In the present study, I follow Dixon's $(1977,2004)$ criteria, according to which, the members of a word class in a given language can be labelled as adjectives when they have certain syntactic and semantic features cross-linguistically typical to adjective classes. They should represent prototypical semantic types of adjectives as dimension, age, value and colour (Dixon 1977, 2004: 3-4, 44), and they should function as either an intransitive predicate or a copula complement and modify a noun in a noun phrase. (Dixon 2004: 14). This definition has been used in this paper in order to restrict the study to concern the potential candidates for adjectives in Nenets, that is, those lexical items whose equivalents in e.g. the European languages belong to a class of adjectives.

Adjectives in the individual languages of the Uralic language family have different morphological and syntactic features, but in all of them, apart from some languages in the Samoyedic branch, e.g. Nenets, adjectives share grammatical features more with nouns than with verbs. In Finnish for example, adjectives are inflected in number and case just like nouns, e.g. suuri 'big', suur-e-lta big-SG-ABL, but they differ from nouns, as they act as modifiers in a noun phrase and agree with their head in number and case (VISK $\S 603$ ). Finnish adjectives in the comparative and superlative can also be inflected. However, there are no absolute rules for the behaviour of adjectives in Finnish either, and in many cases, the line between adjectives and nouns is vague, as the comparative suffix, for example, can be used with some specific nouns, e.g. rannempana ('coast'+COMP+ESS) 'closer to coast').

Nenets, together with its closely related language Enets, are exceptions in the Uralic language family with their verbs used in adjectival functions. In other Samoyedic languages, property words resemble nouns more than verbs, as will be demonstrated in Section 5. However, from a typological viewpoint, it is not rare that languages express properties, in some cases only, with stative verbs. This is the case with Mandarin Chinese (Schachter \& Shopen 2007: 18) and Korean (Sohn 2004), as well as with Japanese, where there are two adjective classes, one with items having similar grammatical properties to verbs and the other to nouns (Backhouse 2004). It is also quite common in the neighbouring languages of Nenets to express properties with verbs. For example, Kolyma Yukaghir possesses qualitative verbs, which are also used in attributive verbal marking, and it lacks a separate class of adjectives (Maslova 2003: 66-70). Also, the system of property concept words in Evenki is quite similar to the system in Nenets. Evenki has three types of adjectives: non-derived, 
so called true adjectives including words for 'good' and 'bad', verbal adjectives that take a participle form in an attributive position, and denominal derived adjectives (Nedjalkov 1997: 276).

Because morphological and syntactic features of property words are different, depending on the language, there are also many different possibilities and criteria for recognizing adjectives in a given language, but there seems to be some typologically common features characteristic to property words or adjectives. Adjectives can be distinguished from nouns and verbs, for example, on the basis of morphological, i.e. derivational criteria, by internal syntax of an NP, by the formation of the comparative construction and, by the formation of adverbs of manner (Dixon 2004: 14-27).

Comparative construction is cross-linguistically common, and thus, it seems to be reliable diagnostic for separating adjectives from nouns and verbs (Hajek 2004: 353). In order to define comparative construction as a cross-linguistically comparable functional category, Stassen (1985: 15) defines it as a "semantic function of assigning a graded position on predicative scale to two objects". This definition is also followed in the present study for a comparative construction in Nenets. According to WALS (Stassen 2011a), there are four types of comparative constructions in the languages of the world: locational comparative, exceeded comparative, conjoined comparative and particle comparative. The first, locational, is the most common in the sample of WALS, and is the one also used in Nenets as well as in other Uralic languages. Also, adverbs as manner, or degree words, have a strong connection to adjectives as property words in syntax and semantics (McNally \& Kennedy 2008, Dryer 2011), and in many languages, they can be derived from adjectives (Schachter \& Shopen 2007: 20). According to Dixon (2004: 11), "in some languages adjectives may also modify verbs, either in plain form or via a derivational process". This can be understood in the way that a modifier of a predicate expressing manner, that is, an adverb derived from a property word, can be interpreted as an adjective, if it fulfils other criteria concerning adjectives.

\section{Major word classes and their predication in Nenets}

In order to explain the difference between the two types of property concepts, verbal and nominal, in Nenets and their morphological behaviour in an NP and predicate position, I will first give a short overview of the structure of the language and its major word classes and their classification criteria.

Regarding word order, Nenets is an SOV language, and as it is typical in this kind of language, a modifier precedes its head in a noun phrase. Moreover, postpositions are used in the language instead of prepositions. The two major word classes are nouns and verbs. In addition, there are minor word classes e.g. postpositions, adverbs and pronouns. Numerals form a subclass of nouns, and on strictly morphological criteria, the same categorization has been applied to property nouns (Salminen 1993, 1997). 
All Nenets verbs are conjugated in person and number in terms of the subject, and transitive verbs can be conjugated in number in terms of the object in the objective conjugation. There is also a group of verbs that can be conjugated in reflexive conjugation. In indicative clauses, the verb stem is followed by a finite stem marker ${ }^{2}$ (see Salminen 1997: 99-103). Depending on how the category of mood is defined, there are 10 to 17 optional non-indicative inflectional mood markers which are mutually exclusive (Salminen 1997: 98, Jalava 2012). These are added to the verbal stem, which can be followed by preceding the possible number of object suffixes and personal suffixes of the subject. Instead of preceding personal suffixes, the past tense marker, traditionally called the preterite, follows them. The preterite marker is only combined with some of the affixes expressing mood (Jalava 2012). The morphological structure and morpheme order of a verbal predicate in Tundra Nenets is illustrated in the following figure (1).

$$
\begin{array}{lll}
\text { STEM } & - \text { [FINITE.STEM }] & -(\text { OBJECT.DU/PL })-\text { SUBJECT }- \text { (PAST) } \\
& - \text { (DERIV })-(\text { MOOD }) & -(\text { OBJECT.DU/PL })-\text { SUBJECT }-(\text { PAST })
\end{array}
$$

Figure I. Structure and morpheme order of a verbal predicate in Nenets.

Example 1 represents the first line shown in figure 1, with the past tense and indicative mood of the first person singular subject from the paradigm of object conjugation with a singular object.

(1) mane?-na-wa-ś

(NenTay2011)

See-FS-OBJ1SG>SG-PRET

'I have seen it.'

Nouns in Nenets can be inflected in case and in number as well as in person and in number of the possessor in possessive expressions. There are two different sets of possessive suffixes: one used with a singular object of possession and another used with a dual and plural object of possession. A case suffix precedes the possessive suffix. In possessed form or non-nominative case, the dual or plural number marking integrate with case or possessive markers in different ways, depending on the form in question. Inflectional suffixes are affixed directly to the noun stem, the marker of the possessor following the case marker, as illustrated in example 2.

(2) yuda-xə?na-ta

(T65: 772)

hand-LOC.PL-3SG.POSS

'in her/his hands'

2. This is glossed as Fs in example 1. In the following examples of verbal forms, the finite stem is not separated from the lexical stem. The form of the finite stem depends on the phonological structure of the verbal stem as well as on the conjugation type used. 
Possessive suffixes are in fact homonymous with personal suffixes of the objective conjugation as seen in $3 \mathrm{a}$ and $3 \mathrm{~b}$.
(3a) məne? $y a-w$
(3b) woesako-w
(NenTay2011)
see- $1 \mathrm{SG}>\mathrm{SG}$
old.man-1sG.POss
'I saw it.'
'my old man'

Both verbs and nouns can act as a predicate of a clause. Verbs can be predicates of transitive and intransitive clauses where they typically express actions and events, and noun predicates are used intransitively when expressing stative relations, "being" something. Nominal predicates are formed by adding the suffixes of the subjective conjugation directly to the nominal e.g. noun or participle stem. ${ }^{3}$ As predicates, nouns are conjugated in person and in preterite tense without using a copula in the affirmative form (see $4 b$ and $4 c$ ). In case of verbal predicates, the same subjective conjugation endings are used in intransitive clauses (see 4a), except for reflexive clauses which use their own paradigm of suffixes (see Tereščenko 1947: 206-219).
(4a) túrya-dm
(4b) woesako-dm
(4c) xańena $a^{4}-d m-\dot{s}$
(NenTay2011)
come-1sG
old.man-1sG
hunter-1SG-PRET
'I come'
'I am an old man'
'I was a hunter'

Even if the verbal and nominal predicate look similar in indicative affirmative sentences, the most significant difference between them occurs in other sentence types: in negation and in some TAM (tempus, aspect, modal) constructions, with the exception of the standard past tense, the preterite (see 4c). In these cases, a predicated noun is followed by copular verb yoeś : ya- 'be (located)'. Salminen (1993) gives a good summary of the word class division and the different cases of predication.

Verbal or standard negation ${ }^{5}$ construction consists of inflected negative auxiliary $n \dot{i}$ - and the non-finite connegative form of the main verb, similarly as in Finnish (cf. tulla 'come' : en (NEG.1sG) : et (NEG.2SG) : ei (NEG.3SG) tule (come-CNG)). In verbal predication, the negative auxiliary takes possible non-indicative mood markers, personal suffixes from subjective, objective or reflexive conjugations, and in the objective conjugation, it also takes the number affixes of the object and the optional preterite suffix as seen in 5. The connegative form cannot be inflected; yet, the main verb in the connegative can be a derived verb. Consequently, derivative suffixes, such as the future marker $-\eta k u$ in 5 , usually do not get affixed to the negative auxiliary, except for the habitive in some cases (Tereščenko 1956: 227-228, Salminen 1997: 53-54).

\footnotetext{
3. When a noun is marked with a possessive suffix (as in example $3 b$ ), acting as a predicate, it cannot be further affixed with verbal endings.

4. In fact, xanena is the present participle form of the verb xane- 'hunt'. In Nenets, there are no specific derivative suffixes or other specialized means for producing actor words, but present participles are used instead, and their morphosyntactic behaviour is similar with other nouns.

5. Miestamo (2011) defines standard negation as the basic way a language has for negating declarative verbal main clauses.
} 
(5) ńí-wa-ś

temta- $\eta k u-?$

(NenTay2011)

NEG-OBJISG $>1$ SG-PRET buy-FUT-CNG

'I would not buy it.'

Interestingly, Nenets uses double predication when the copula is needed with predicate nouns. In these cases, both the predicate - the nominal predicate - and the copula verb, in the case of special TAM forms or the negative auxiliary, are conjugated in terms of the subject, as shown in the following negative sentence (example 6).

(6)
xańena-dm
ní-dm
ya-?
hunter-1sG
NEG-1SG
COP-CNG
'I am not a hunter.'

(NenTay2011)

The following examples demonstrate the difference between mood constructions with a nominal and a verbal predicate. In 7, the noun xanena 'hunter' cannot take the mood marker, so the suffix of the narrative mood -wi is affixed to the copula. As for verbal predicates, the marker of obligative mood -bsake is affixed directly to the verb stem in 8 .

$\begin{array}{lll}\text { ta-h mal'ykana } & \text { xańena } & \text { yce-wi } \\ \text { that-GEN during } & \text { hunter } & \text { COP-MOD.3sG } \\ \text { 'At that time, he was a hunter.' } & \end{array}$

(NenTay2011)

'At that time, he was a hunter.'

(8) xúńana to-bsake-dm

tomorrow come-MOD-1SG

(NenTay2011)

'I will most probably come tomorrow.'

As seen in the past tense examples 1 and $4 \mathrm{c}$, the inflectional standard past tense, the preterite, is identical in both verbal and nominal predicates, its suffix $-s$ following the personal suffixes. However, the future tense, which is a derivative form, as demonstrated in 5, as well as aspectual derivatives such as the habitive, form different kinds of constructions with predicated verbs and nouns. Just like negation, they use the copula construction. The same applies to the non-indicative moods, as demonstrated with the help of a nominal predicate in 7 and verbal predicate 8 .

This section has discussed the difference between the two main word classes in general and especially in the predicate position where their difference is not transparent in affirmative indicative sentences. Division of the property concept words into two major word classes is based on the syntactical rules presented here, but they differ from each other in the attributive position as well, as will be presented in the next section. 


\section{Syntax of the property concept words}

In this section, I will examine the syntax of the property concept words comparing them to other nouns and verbs and finding syntactic features typical or limited to property concepts. I will demonstrate the morphosyntax of the property words in the attribute and predicate position and justify their division in two major word classes applying the criteria presented in Salminen (1993). I will also investigate different types of predicates as well as the internal syntax of noun phrases in order to find features typical to property words. First, I will show examples on predication of the property concept words and then explore the internal syntax of the noun phrase with an attributive noun or verb.

The morphology of nouns and intransitive verbs as modifiers in noun phrases and as predicates is summarized in Table 1 below, and it applies to the property words representing two different word classes as well. The clause examples in the table, demonstrating the morphosyntax of the property nouns and verbs, will be explained and translated in more detail in Section 4.1 to 4.3. The numbers refer to the glossed examples of each type of sentence analysed hereafter.

\begin{tabular}{|c|c|c|}
\hline \multirow{2}{*}{$\begin{array}{l}\text { Predicate: } \\
\text { affirmative, } \\
\text { indicative }\end{array}$} & N-SUBJ & V-SUBJ \\
\hline & $\begin{array}{l}\text { (9b) } t i \text { ser } \\
\text { 'the reindeer is white' }\end{array}$ & $\begin{array}{l}\text { (9a) ti porid'e } \\
\text { 'the reindeer is black' }\end{array}$ \\
\hline \multirow{2}{*}{$\begin{array}{l}\text { Predicate: } \\
\text { negative }\end{array}$} & $\mathrm{N}-\mathrm{SUBJ}+\mathrm{NEG}-\mathrm{SUBJ}+\mathrm{COP}-\mathrm{CNG}$ & NEG-SUBJ + V-CNG \\
\hline & $\begin{array}{l}\text { (11) ti ser ńi } \eta a-? \\
\text { 'The reindeer is not white'. }\end{array}$ & $\begin{array}{l}\text { (10) ti n'i porid'e-? } \\
\text { 'The reindeer is not black.' }\end{array}$ \\
\hline \multirow{2}{*}{$\begin{array}{l}\text { Predicate: } \\
\text { non-indicative }\end{array}$} & N-SUBJ + COP-MOD-SUBJ & V-MOD-SUBJ \\
\hline & $\begin{array}{l}\text { (13) ma?-ma? ṕirća yoe-wi } \\
\text { 'The tent turned out to be tall.' }\end{array}$ & $\begin{array}{l}\text { (14) jib́b-tarxa } \\
\text { 'She seems to be smart.' }\end{array}$ \\
\hline \multirow[t]{2}{*}{ Modifier in NP } & N-Ø & V-РТСР \\
\hline & $\begin{array}{l}(27 \mathrm{~b}) \text { ser } t i \\
\text { 'white reindeer' }\end{array}$ & $\begin{array}{l}\text { (27a) pərid'e-ńa } t i \\
\text { 'black reindeer' }\end{array}$ \\
\hline
\end{tabular}

Table I. Syntax of the property words in the attributive and predicative position.

In the predicate position, both verbs and nouns agree in person and number with the subject, as was demonstrated in the previous section. As a modifier in a noun phrase, a noun is in unmarked nominative form and usually does not agree with its head. Verbs can appear in a noun phrase only in non-finite form: as a modifier they take the form of a participle. 


\section{I. Property words and predication}

The two different types of property concept words obey the same principles of predication as other verbs and nouns which were introduced in the previous section. The following examples illustrate the same syntactic difference between verbal and nominal predicate for property concepts. The two colour terms in $9 \mathrm{a}$ and $9 \mathrm{~b}$ are predicates of the sentences appearing in subjective conjugation form which is unmarked in the case of third person singular (cf. examples $4 \mathrm{a}$ to $4 \mathrm{c}$ ).
(9a) $t i$
parid'e
reindeer be.black.3sG
(9b) $t i$
reindeer white.3sG
'The reindeer is black.'
'The reindeer is white.'

(NenTay2011)

In Nenets, 'black' and 'white' belong to different major word classes; parid'e(s) '(be) black' is a verb, while ser, serako 'white' is a noun, which can first of all be seen in their different negation structure. The negation of the verb parid'e(s) 'be black' (see example 10) is formed as standard negation of any verbal predicate (as seen previously in example 5).

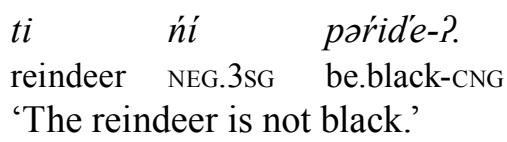

(NenTay2011)

However, in the negated predication of the noun ser 'white', the copula construction is used as in 11, (cf. also example 6) and the noun cannot be formed in the standard negation without the copula, see 12 .
(11) $t i$
$\begin{array}{llll}t i & \underline{s e r} & \underline{n} i & \frac{\eta a-?}{\text { NEG.3SG }}\end{array}$
'The reindeer is not white.'
(12) *ti ńi ser-?
reindeer NEG.3SG white-CNG
'The reindeer is white.'

In addition to the negation rule, non-indicative moods as well as the future tense and the habitive aspect can also be used as an indication when identifying property words as nouns or verbs in the predicate position. In the case of non-indicative moods, the future tense and the habitive aspect, the copula construction is used with any nominal predicate, also with property word predicates, as in example 13 and as seen in example 7 above. 

(13) mar-ma? ṕirća noe-wi
tent-1PL.POSS high COP-MOD.3SG
'The tent turned out to be tall.'

(T65: 451)

In the case of verbal property word predicates, the mood markers are affixed directly to the verbal stem as in 14 .

(14) jíbe-tarxa

(NenTay2011)

(be)smart-MOD.3sG

'She seems to be smart.'

As previously seen in $9 \mathrm{~b}$ and 11 , nouns that express property can be predicated just like other nouns. According to Payne's (1997: 111-112, 114) terminology, six different types of predicate nominals can be distinguished: proper inclusion, equation, attribution, location, existence and possession. To refer to these types of sentences, I adopt the term stative relation clause from Hamari (2007), who uses it in her study on the Mordvin languages. From the perspective of Nenets, the most significant stative relation clauses are the first three in Payne's list (proper inclusion, equation, attribution), which are expressed with non-copula nominal predicates in affirmative indicative sentences; see 15 to 17, whereas location, existence and possession, are expressed with a copula construction or existential verbs.

Proper inclusion: (cf. Frieda is a teacher. (Payne 1997: 111))
(15) mań Usport-h terə-dm
I Usport-GEN inhabitant-1sG

(NenTay2011)

'I am an inhabitant of Usport'

Equation: (cf. He is my father. (Payne 1997: 114))

(16) tiki puxaća-w

(T65: 492)

this old.woman-1sG.Poss.3sG

'This is my wife'

Attribution: (cf. John is tall (Payne 1997: 112))

(17) tuku ne jilxi
this woman youg.3sG
'That woman is young.'

(NenTay2011)

In proper inclusion and equative sentences (as seen in 15 and 16), the predicated noun typically refers to items and entities, with the first and second person subject usually referring to humans (see 15 and 16) and with third person subjects also referring to inanimate entities. Attribution (as in 17) is the type for expressions of property and quality in the predicate position, representing the prototypical semantic types of adjectives. 
Predicated nouns in attributive predication sentences as in 17 are formally identical with the other semantic types of nominal predicate clauses as in 15 and 16, in affirmative and negative sentences, as well as with mood and aspectual markers. Similar predication strategies of property words and other nouns is typically the case in languages in which adjectives do not form a grammatical category different from nouns (Payne 1997: 111-112). This shows that property concept nouns in Nenets cannot be differentiated from other nouns in the predicate position, just like property concept verbs are similar to other intransitive verbs (cf. 'come' in 4a and 'be black' in 9a). For semantic reasons, some moods, such as the imperative, are not used with property words, but this kind of negative evidence based on the semantics of the words cannot be considered a criterion distinguishing property words from other nouns and verbs.

\subsection{Property nouns as attributes}

Within a noun phrase, a modifier does not agree with its head in case (see 18a and 18b), and it appears in the unmarked nominative case preceding the head. In fact, the property nouns cannot usually be inflected in a case at all.
(18a) yarka poyka
(18b)
yarka
poyka-xəna
big
net-LOC
big net
(NenTay2011)
'a big net'
'in a big net / with a big net'

Agreement in number and possessor is possible (Tereščenko 1965: 884), but, on the basis of my data, modifiers without agreement seem to be much more common compared to noun phrases with agreement. Salminen (1998: 544) suggests that agreement of the modifier in number depends on "the particular focus relations", but without given examples or justification, the explanation remain a hypothesis to be tested in the future. It seems that, at least to some extent, the agreement in number of the head is focused on lexicalized compound words in which the meaning of the modifier is more or less figurative more than literal, as in 19 'big days' referring to a festival.

(19) yarka-? jal'a-? xaxjaltni-ad?

(T65: 759)

big-PL day-PL approach-REFL.3PL

'The festivals were approaching.'

In Nenets, property words are the most common nouns appearing in the nominative case as a modifier, as possession or the relation of two nouns is expressed with the genitive construction. However, modification of the nominative case in a noun phrase cannot be considered a distinguishing criterion unambiguously. There are also noun phrases in which a noun with no prototypical adjectival semantics modifies another 
noun as a noun adjunct appearing in the nominative case. In example 20, the word 'woman' modifies its head 'child' giving the compound word the meaning 'female child' $\rightarrow$ 'girl'.

$\begin{array}{ll}\text { (20) ńe } & \text { yoćeki } \\ \text { woman } & \text { child } \\ \text { 'girl' } & \end{array}$

(NenTay2011)

From a semantic viewpoint, it makes sense that ne 'woman' is not a property concept but a noun referring to a person. Another interpretation would be 'female' as a human property, or both, assuming that adjectival nouns cannot be distinguished from other nouns. As semantic differences cannot be used as criteria, and there is no difference between the use of the words ne 'woman' and yarka 'big' in the attributive or predicate position, further tests are required in order to find out if they have grammatical differences.

Siegl (2013: 140) has reported that in Forest Enets, a closely related language to Nenets, adjectives cannot usually be used without the noun they modify and they cannot appear as the complement of postpositional phrases. This seems to apply to Nenets property nouns too relatively well: in my data, at least nouns that express dimension, age, value, and colour are only rarely found without the head they modify or as a complement in a postpositional phrase. According to Siegl (2013: 140), the only case in Enets in which adjectives appear without a noun they modify, is when the adjective is marked with possessive suffix. The same applies to Nenets, as seen in example 21, where the adjective 'nud'a 'small' appears in possessed form individually as a subject of the clause. The meaning is not 'their small', but 'the small(est) of them'. In this sentence, the meaning can be interpreted as contrastive: contrary to expectations, it was the youngest who got married, not one of the older brothers.
(21) ńud'a-doh yarka ńi-ta nerńa
small-3PL.POSS big brother-GEN.PL3SG.POSS before
'the youngest of them before his big brothers'
ńel'e-j?
get.married.REFL.3SG
'got married'

'(It was) the youngest of them (who) got married before his older brothers.'

Thus, Nenets seems to represent the typological type in which an adjective may occur without noun, obligatorily marked by suffix (Gil 2011), in Nenets, the possessive suffix. Yet, there are examples of property nouns appearing as the head of a noun phrase without a possessive suffix. It seems that only a limited amount of the most prototypical property concept words have this kind of independent, possibly ellipsed use. 


$\begin{array}{llll}\text { (22) } & \text { no-ńi } & \text { yoka wowa-m śertaə- } n \\ \text { on/for-1sG much bad-ACC do-2sG } & \end{array}$

'You have caused me a lot of harm.'

For comparison, also in Finnish, as well as in many other languages, certain adjectives can take the position of nouns as the subject or object of the sentence. One essential group of words to which this applies in Finnish are adjectives referring to an abstract entity, such as 'good' and 'bad' (VISK § 625-627).

\section{(23) Olet teh-nyt paha-a be-2sG do-PTCP.PST bad-PART}

'You have done (something) bad.'

This kind of limited use could explain the occurrences of individual property nouns forming a noun phrase in Nenets as well. In some cases, property nouns have to be seen as lexicalized as nouns with reference items and events. In the following example, the rule of a property concept noun not appearing as complement of a postposition is violated.
(24) ṕirća-h ńińa nú-dm tall-GEN on-LOC stand-1sG 'I stand on a highland.'

This sentence is from Tereščenko, and its translation (originally in Russian) 'I stand on a highland' suggests that some nouns, as pirća here, can be used referring not only to property but also to an item representing the given property.

In most cases, however, postpositions require a noun other than a property word as their complement. The postpositional phrase in example 25 would be incorrect (26) if the word yarka would be a complement for the postposition without its head nita 'brothers'.

$$
\begin{aligned}
& \text { yarka ní-ta nerńa } \\
& \text { big brother-GEN.PL3SG.POSS before } \\
& \text { 'before his older brothers' }
\end{aligned}
$$
(26) *yarka(-h) ńerńa big(-GEN) before 'before big'

It seems that despite the exceptions introduced above, the head of the noun phrase in Nenets is most typically not a property word which, for one, is a typical modifier of the head noun. Consequently, property words do not appear in benefactive form or predestinative declension (Salminen 1997: 129-130). In conclusion, the morphosyntax of property nouns within a noun phrase gives reason to consider them to be a special subgroup of nouns. 


\subsection{Property verbs as attributes}

Already Castrén (1854: 186-187) reports that some Nenets adjectives require the suffix $-d a\left(n a \sim t a \sim t^{\prime} a\right)$ in an attributive position, which does not appear in the predicate position. His observation concerns the main difference between the two types of property concept words as modifiers in a noun phrase: verbs expressing property take the participle form when they are used attributively as the verb téç(ś) '(be) cold' in $27 \mathrm{a}$.
(27a) téć̀-da jal'a
be.cold-PTCP day
'a cold day'
(27b) jal'a-da $\quad \underline{\text { téća }}$ day-3sg.Poss cold.3sg
'The day is cold'
(Castrén 1854: 187)

The difference between the two types of property concepts in the attributive position is clear: when modifying a noun, a stative verb appears in participle form as in $28 \mathrm{a}$, whereas nouns are in an unmarked basic form $28 \mathrm{~b}$.
(28a) paŕid'e-ńa $t i$
be.black-PTCP reindeer
'a black reindeer'
(28b) $\mathrm{ser} \quad t i$
white reindeer
'a white reindeer'
(NenTay2011)

The use of a participle or other nominalized verb form in the attributive position, as a modifier in a noun phrase, is a phenomenon known in many other languages too. For example, in Evenki (Nedjalkov 1997: 75), stative verbs appear in participle form as modifiers in a noun phrase, just like in the Nenets example above. Also in Finnish, as seen in (29a and 29b) participles are used in an attributive position. Also in English, some participles function as attribute when nominalized, which can be seen in the translation of $29 \mathrm{~b}$.
(29a) tyttö juokse-e
girl run-3sG
'The girl runs'
(29b) juokse-va tyttö
run-PTCP girl
'the running girl'

In Finnish, some participles that are used in attributive positions resemble adjectives, or, some present participle forms have been lexicalized into adjectives, e.g. vakuuttava 'convincing' from vakuuttaa 'assure' (see Koivisto 1987 for more details on the adjectival use of participles). Adjective-like use of a nominalized verb form can also be observed in English convincing as well as in the translation of example $28 \mathrm{~b}$ where the present participle form running modifies the noun. In Finnish, as well as in

\footnotetext{
6. The possessive suffix - $d a$ in the subject of example 26b, jal'a 'day', is used as a marker of definiteness. It is confusingly homonymic with the variant $-d a$ of the present participle marker $(-n a, \sim n a, \sim d a$, $\sim t a, \sim t^{\prime} a$ ), especially when presented in this pair of example sentences, and therefore requires an emphasis of its different function and classification.
} 
English as seen again in the translation, participles also share some features typical to adjectives, e.g. the comparative vakuutta-va-mpi 'more convincing'.

The most important difference between participle attributives in Finnish and Nenets from the viewpoint of property concept words is in the semantics of the nominalized verbs. In Nenets, the participial attributes can also be formed from verbs that have the meaning of Dixon's (1977; 2004: 14) typical adjectival semantic types, i.e. temperature or colour. For Finnish or English, or any other language in which property concepts resemble nouns more than verbs, the roots of the participial modifiers in the noun phrase never have a prototypical adjectival meaning. According to Hopper \& Thompson (1984: 728), it is more likely for lexical items with a more stative meaning to be incorporated into a noun phrase as an attribute than i.e. active participles, whose meanings are close to instantaneous actions. This seems to apply to Nenets to some extent, as stative verbs and verbs carrying the meaning of property seem to be the most typical participial modifiers appearing individually without additional modifiers. However, also other verbs than expressions of property can act as participial modifiers in a noun phrase, but typically only as part of a modifying phrase as in example 30.

(30)

$\begin{array}{lll}\text { tukuxəna } & \text { məncəra-na } & \text { ńe } \\ \text { here } & \text { work-PTCP } & \text { woman }\end{array}$

'The woman who works here'

Thus, it can be argued that independent participial modifiers are most typically property verbs, and other verbs usually appear with a complement in a modifying relative clause.

In addition to the present participle (demonstrated in example 30), the past, future and negative participle forms can also act as modifiers in a noun phrase. In example 31, the past participle form modifies the noun.
(31) $x a-w i \quad t i$
die-PTCP.PST reindeer
'dead reindeer'
(NenTay2011)

In Nenets, the present participle is also used as an agentive suffix, e.g. xane-na (huntPTCP) 'hunter', as explained earlier in the footnote concerning of example 4c. In noun phrases, the lexicalized agentive nouns such as xańe(-)na 'hunter, the one who hunts', cannot be differentiated from attributive forms of property verbs such as príide-ńa (be.black-PTCP) 'the one who is black' in any other way than by their internal morphosyntax in the noun phrase. Lexicalized agentive nouns can be inflected in a case, and they can appear as head of a noun phrase, whereas participles of property verbs usually appear in the unmarked nominative case and only when modifying a noun. Yet, lexicalized agentive words can also be used individually as nonverbal predicates as seen in example 32 . 
(32) xańe(-na)-dm

(NenTay2011)

hunter(-PTCP)-1sG

'I am a hunter'

Of course, the boundary between verbs used in an attributive position and formally identical agentive nouns is wavering, and the participle form of the same verb may in one context be used as an agentive noun, and in another context as a modifier. Contrary to the previous example (32), stative verbs with an adjectival meaning do not usually act as predicates taking the participle form.

\section{Semantic types and explaining lexical categorization of property words}

In this section, I will take a closer look at the semantic content of Nenets property words in both main word classes. I assume that by investigating the history of the property words, it can be explained why they are split into two different word classes. Thus, I will see which types of property words belong to which major word class and draw a preliminary hypothesis on the polarization of property words.

Four of Dixon's $(1977,2004)$ seven semantic adjectival semantic types are socalled core types that are typically associated with both large and small adjective classes in the languages of the world: dimension, age, value and colour. This means that if a language has an adjective class at all, the adjectives will probably express at least some of the four core semantic types. (Dixon 2004: 3-4, 44.) In Nenets, three of the four core semantic types are most typically nouns, for example.

Nouns:

yarka 'big', ńud'a 'small', joŕa 'deep', ṕirća 'high, tall' (dimension)

jedej 'new', newxi 'old' (referring to an inanimate

object), woesej 'old, aging', jilxi 'youg' (age)

sawa 'good', waewa 'bad', nenej 'real' (value)

Moreover, there are also verbs expressing these semantic types, such as tarka- '(be) narrow' (dimension). Colour terms represent either nouns or verbs. These are also lexical items belonging to other semantic types associated with adjectives: speed, physical property and human propensity. These include, for example:

Nouns and verbs:

colour: pəríide(s') '(be) black (V)', ser, 'white (N)', naja(s)

'(be) red' (V), taśexej 'yellow' (N)

speed: lak 'fast' (N), méreć '(be) fast' (V)

physical property: teća(s) '(be) cold' (V), jepo(ś) '(be) hot' (V), śibić 'light' (N)

human propensity: śadoć '(be) beautiful' (V), śenc 'healthy' (N), jíbeć '(be) clever' (V), jil'ebad'o(s) '(be) happy' (V) 
Dixon's (2004: 3-4, 44) argument on core semantic types being most typically associated with adjective classes of any size can be tested and applied to Nenets as well. The fact that most of the core semantic types in Nenets are expressed with nouns but not verbs suggests that these nouns may have belonged to a small class of noun-like adjectives in the earlier state of the language. This argument is supported by the case of Enets where there is a small, closed set of noun-like adjectives (Siegl 2013: 140) including cognates of those Nenets words that represent the core semantic types. The most typical nouns expressing dimension and value in Nenets can be traced back to Proto-Samoyed where they are property nouns as well (Janhunen 1977). Other property words traced back to Proto-Samoyed - or Proto-Samoyedic reconstructions with an adjectival meaning - are either nouns or verbs, and they have maintained their reconstructed word class in Nenets.

The table below includes all of the words presented in Janhunen (1977) with a typical adjectival meaning. Most of them have remained in Nenets. Examples are given in Tundra Nenets, if the word exists in the language, and the reconstructed meaning, if it differs from the meaning in Nenets, is given in the end.

\begin{tabular}{|c|c|c|}
\hline $\begin{array}{l}\text { Semantic } \\
\text { type }\end{array}$ & Nouns & Verbs \\
\hline Dimension & $\begin{array}{l}\text { ńud'a 'small' } \\
\text { yarka 'big' } \\
\text { pirća 'high, tall' } \\
\text { xcem 'short' } \\
\text { lamto 'low' }\end{array}$ & \\
\hline Value & $\begin{array}{l}\text { sawa 'good' } \\
\text { wowa 'bad' }\end{array}$ & \\
\hline Age & $\begin{array}{l}\varnothing \\
\text { (in Nenets jedej 'new', } \\
\text { newxi, woesej 'old') }\end{array}$ & \\
\hline Colour & ser 'white' & ńarja(s) '(be) red' \\
\hline Speed & $\begin{array}{l}\text { merh (particle) 'quickly' } \\
\text { (PS 'fast') }\end{array}$ & méreć '(be) fast' \\
\hline $\begin{array}{l}\text { Physical } \\
\text { property }\end{array}$ & $\begin{array}{l}\text { síbić 'light' } \\
\text { talw 'the darkest moment of } \\
\text { the night' (PS 'dark') } \\
\text { paj 'askew' } \\
\text { ner 'sap' (PS 'wet') }\end{array}$ & 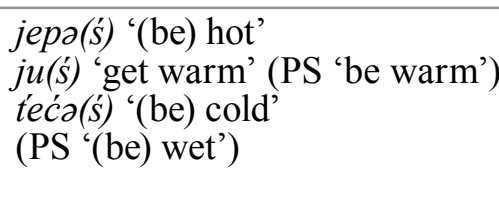 \\
\hline $\begin{array}{l}\text { Human } \\
\text { propensity }\end{array}$ & PS 'angry' & ńenə(s') 'be/get angry' \\
\hline
\end{tabular}

Table 2. Nenets property words derived from Proto-Samoyedic words with adjectival semantics. 
At least three of the nouns here representing adjectival semantics, but none of the verbs, can be traced back to Proto-Uralic, which means that these nouns are old, and that also noun-like property words are an old phenomenon. These nouns are pirća 'high, tall' which has a cognate e.g. in Finnish pitkä 'high, tall' (UEW 377), ner 'sap' $\leftarrow$ 'wet' goes back to Proto-Uralic 'wetness, wet place' (Aikio 2006: 20), and lamtik 'low' goes back to Proto-Uralic *lamte 'low' (UEW: 235). It is possible that some other Proto-Samoyedic nouns representing adjectival meaning, e.g. talw 'the darkest moment of the night', also indirectly originate from Proto-Uralic *tälwä 'winter' (UEW 516) as loanwords from related languages.

Most of the other Samoyedic languages express properties mainly with nouns. In addition to Nenets, its closest related language Enets uses stative verbs to express qualities, in participial form as attributes and inflected as a rule as predicates. The two other groups of Samoyedic languages that are spoken today, Nganasan and Selkup, express properties mainly with nouns or with adjectives that form a subgroup of nouns. Nganasan uses different markers for adjectives, most frequently the adjective marker kəə ( gəə) (Wagner-Nagy 2002: 86-87), and adjectives in Selkup are usually marked with the suffix $-l^{\prime}$ (Helimski 1998: 562). In both languages, just like in Nenets and Enets, there are also non-derived property nouns or adjectives that seem to derive from Proto-Samoyed, i.e. Nen sawa 'good' Enets soiđa 'good' Selkup soma 'good', (Janhunen 1977: 132-133, Helimski 1998: 562, Siegl 2013: 141) and Nenets woewa 'bad' Nganasan bah'a (Wagner-Nagy 2002: 86).

It seems that at least the core semantic types of adjectives were expressed with nouns in Proto-Samoyed because they seem to be mostly non-derived nouns in the current Samoyedic languages. On basis of this, it can be hypothesized that basic adjectival words have, in an earlier state of the language - in Proto-Samoyed, likewise possibly in Proto-Uralic - either formed a separate possibly small words class of adjectives, or, they have been part of the class of nouns, and expressing property with verbs is a newer innovation, concerning mostly Nenets and Enets. This hypothesis is supported when taking a closer look at Proto-Samoyedic verbs with adjectival meaning in the table above. Most Proto-Samoyedic adjectival verbs do not have continuators in Nganasan and Selkup, and, part of those that do, the continuators are not verbs.

In Nenets, stative verbs seem to most typically express adjectival semantic types other than the four core types: dimension, value, age and colour. Most typically, they express physical property and human propensity: jepə(s) '(be) hot', tećə(s') '(be) cold, miŕeć '(be) expensive', mebeć '(be) strong', terśa(s') '(be) empty', saykowoć '(be) heavy', ńayoć '(be) thick', śadoć '(be) beautiful', jíbeć '(be) clever', jil'ebad'o(s') '(be) happy', maykbə(s) '(be) poor', śeroć '(be) sly'. In the context of the Siberian languages, this tendency is not an exception at all. It can be assumed that the verbal expressing of properties has developed in Nenets and Enets as result of contacts with other non-Uralic Siberian languages with adjectival stative verbs. For example, Yukaghir and Evenki represent the verbal type of property words (Maslova 2003: 66-70, Nedjalkov 1997: 276). 
A relatively small amount of Uralic vocabulary has remained in the Samoyedic languages as a whole (Janhunen 1998: 475), which means that the majority of vocabulary in the Samoyedic languages has been borrowed, and among it assumingly also a great number of property concept words. But as the history of Samoyedic words is relatively unknown, conclusions cannot be drawn without further investigation on the topic. However, it can be assumed that expressing adjectival meaning with stative verbs has been adopted in the Samoyedic languages, mainly in Nenets and Enets, simultaneous with borrowing new vocabulary, and among it also adjectival stative verbs. Still, Nenets among some of the other Samoyedic languages has maintained non-derived nouns as expressions of dimension and value. In Nenets, property concepts that express e.g. similarity to something and a comitative state or being with something can be productively derived from nouns. The similarity suffix -roxa has been reconstructed back to Northern Samoyed, but -(e)j, -l'ayk and the comitative -sawej seem to be newer innovations, as property concepts are formed mainly with different suffixes in other Samoyedic languages.

\section{Typical adjectival features of property concept words}

\section{I. Derivational characteristics}

Derivation is a typical way of forming adjectives in many languages with open word classes that can productively take new members. Nenets also has, in addition to nonderived property concept words such as sawa 'good', certain derivational suffixes which are used to produce describing words from other nouns or verbs. Derivational suffixes give nouns or verbs a meaning of quality or property, usually without changing the main word class, e.g. jisawej 'smart, sensible' from ji 'mind, sense'.

In addition to derivational suffixes that produce property words, there are also derivational suffixes that can only be affixed to property words changing their meaning nuance sawa 'good' $\rightarrow$ sawarka 'better'. These derivational features could even be considered to be a morphological criterion for recognizing and dividing property words as adjectives forming subclasses of nouns and verbs, at least together with syntactic features that will be introduced in sections 6.2 and 6.3 .

Derivational suffixes that are used in forming property words has been analysed well by Tereščenko $(1956: 157-181=$ T56). She describes a few suffixes that are used productively, deriving property concept nouns from common nouns. These suffixes are:

-rəxa: ńíbaraxa 'needle-like' $\leftarrow$ ńíba 'needle'

(T56: 158)

-sawej: nesawej 'married (man)' (literally 'with a woman')

$\leftarrow$ ńe 'woman'

-l'ank: pedaral'ank 'wooded' $\leftarrow$ pedara 'forest'

$-i(\sim x i,-g i,-\eta k i,-n i j,-i j)$ : warxi 'outermost' $\leftarrow$ war 'edge'

wínki 'tundra-' $\leftarrow$ wih 'tundra'

(T56: 161) 
Derivatives with -sawej are labelled as comitatives (Salminen 1998: 541-543), and they have the special meaning 'with something'. The derivative suffix -raxa ( laxa), the simulative (Salminen 1998: 541-543), produces the meaning of likeness and similarity, and it is a common Northern-Samoyedic adjectival derivative suffix (Mikola 2004: 114). In Nenets, it is a productive suffix that can be used in forming words with descriptive properties from almost any noun. The simulative has also produced lexicalized property words, the meaning of which is more opaque. These are especially some colour terms (Tereščenko 1956: 159):

$$
\begin{aligned}
& \text { śunraxa 'blue' ('steam-like') } \longleftarrow \text { śun 'steam' } \\
& \text { pəd'arzxa 'green' } \leftarrow \text { pəd'a 'bile' } \\
& \text { yamte?loxa 'green' } \leftarrow \text { yamte? 'grass' }
\end{aligned}
$$

Among the property nouns, there are words ending with $-(e) j$ and $-k$ that seem to be opaque derivative forms whose root cannot be identified (Tereščenko 1956: 158):

$$
\begin{array}{ll}
\text { jedej 'new' } & \text { nulak 'soft' } \\
\text { xasuj 'dry' } & \text { lamt'ik'low' }
\end{array}
$$

Derivation can also change the word class from noun into a property word representing the word class of verbs. This is the case with the caritive suffix:

$$
\begin{aligned}
& \text { śi 'hole' } \rightarrow \text { śíśa(ś) '(be) unbroken' ('without a hole') } \\
& \text { ter 'content' } \rightarrow \text { térśa(s') '(be) empty' ('contentless') }
\end{aligned}
$$

Derivation can also be other way around. Tereščenko (1956: 162) describes a deverbal derivative suffix, and with this suffix property nouns can be derived from stative verbs e.g.

$$
\text { -j: xanuj 'ill' } \leftarrow \text { xaykurć 'be ill' }
$$

In addition to denominal and deverbal property derivatives, there are derivational suffixes that can be affixed only to property concept words, but not other nouns and verbs. Thus, these derivational suffixes can be used as a test when identifying and distinguishing property words. There are three derivational suffixes which, in my data, are found only affixed to property nouns: comparative, moderative and augmentative (names according to Salminen 1998: 541-543, also introduced in Tereščenko 1965: 886).

Comparatives: $\quad$ sawa 'good' $\rightarrow$ sawarka 'better' saykowoć '(be) heavy' $\rightarrow$ saykowosrka'be heavier'

Moderatives: $\quad$ sawa 'big' $\rightarrow$ sawampoj 'rather big' 
The comparative derivative is used to express a greater grade of the property, and it can be affixed to both nouns and verbs, as will be demonstrated in examples 37 and 38 in the next section (6.2).

$\begin{array}{lll}\text { (33) tedah } & \text { xəćah } & \text { sawa-rka-dm } \\ \text { now } & \text { almost } & \text { good-comp-1sG }\end{array}$

'Now I feel somehow better.'

For the comparative construction, as defined in Section 5.1, the comparative suffix if not obligatory, and its function is not comparing qualities of two items but instead it expresses the increasing grade of the given property.

The moderative gives an adjective additional nuance 'rather', e.g. yarka 'big' $\rightarrow$ yarkampoj 'rather big', as for augmentative; it strengthens the meaning of the adjective, e.g. yarka 'big' $\rightarrow$ yarka?ja 'very big'. It seems that the moderative and augmentative suffixes can only be affixed to property nouns and the comparative can be affixed to either nouns or verbs carrying the meaning of property.

\subsection{Comparative construction}

The comparative construction here refers to a construction where properties of two elements are compared, and which consist of a gradable predicate, and two objects (Stassen 1985: 15; 2011), and it should not be confused with the comparative suffix described in the previous section, which, for one, can be used in describing only one object, and which is not obligatorily used in the comparative construction.

The most common strategy of forming the comparative construction in the world's languages, according the sample of WALS (Stassen 2011a), is the locational strategy which is also used in Nenets. In Nenets, the comparative construction is formed with the help of an ablative construction, as demonstrated in examples 34 and 35. The comparee noun phrase is the subject of the clause and precedes the standard $\mathrm{NP}$, and the latter is in the ablative case. The last feature is the property word which is predicated agreeing with the subject.

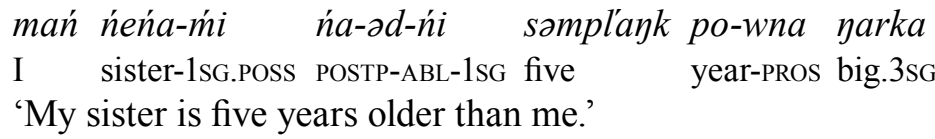
ténana numta ńi-ś
téci-?
tuku jal'a-xad
yesterday weather NEG-3SG.PRET be.cold-CNG this day-ABL
'Yesterday, the weather was not colder than it is today.'

(NenTay2011)

Depending on the exact nature of the function of the locational marking, Stassen (2011) divides the locational comparatives into three further subtypes: from-comparatives, to-comparatives, and at-comparatives. Nenets represents the from type with 
its ablative construction, and other Uralic languages also use the same construction (Raun 1960); furthermore, outside of the Uralic language family, for example Evenki (Nedjalkov 1997: 278) and the Turkic languages (Stassen 2011a) use this construction.

In examples 34 and 35, the predicate of the sentence is a verb. However, not every sentence with a subject, a nominal complement in the ablative case and an intransitive verb is a comparative construction. The same morphosyntactic structure of the clause is possible in following example (36) as well.

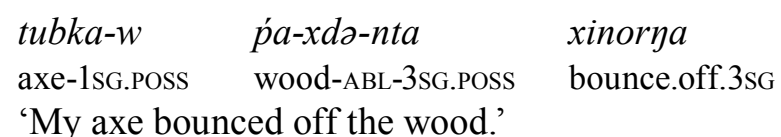

(T65: 792)

'My axe bounced off the wood.'

Of course, the interpretation is not 'the axe is more bouncing than the wood', but 'The axe bounced off the wood'. This interpretaion is a default, because the meaning of the verb is not a state but an event. In the case of verbal predicates, the comparative interpretation of the construction is possible only in case of verbs that express property. This can be regarded as some kind of tendency for distinguishing property verbs from other intransitive verbs. However, as there is no formal difference between the clauses, the meaning of the construction is the only distinguishing feature.

The comparative construction is used equally with predicated nouns as in example 37 below. Contrary to comparative construction with a verbal predicate, the nominal predicate in a comparative construction is always a property word. Thus, a construction with [NP-NOM NP-ABL N-PREDICATE] can be used as a test when distinguishing property nouns from other nouns, as there are no morphosyntactically homonymous counter examples such as example 36 for comparative constructions with verbal predicates.

An optional comparative derivational suffix is often affixed to the predicate noun as in example 37 , and it can be used with a predicated verb in comparative construction as well, as seen in examples 38 .

\section{jam to-xad yarka-rka \\ sea lake-ABL be.big-COMP.3sG}

(T65: 386)

'The sea is bigger than the lake.'

(38) ńad-ńi sas-rka-we-n

on/from-1sG be.strong-COMP-MODER-2SG

(T65: 537)

'You are stronger than me.'

The comparative derivative distinguishes the comparative construction from morphosyntactically identical clauses with an action or event verb. However, the use of the suffix is not obligatory, so it does not offer any formal criterion for distinguishing adjectival stative verbs unambiguously, and the comparative construction can be used as a formally distinguishing criterion for property nouns only. 


\subsection{Adverbs of manner}

The connection between property words and adverbs of manner (McNally \& Kennedy 2008, Dryer 2011) can be seen in Nenets relatively well, as adverbs of manner are formed from property concept words with the help of the suffix -wana $(\sim w n a)$ in case of nouns or by using the modal gerund $\left(-s^{\prime} \sim \dot{c} /-\partial\right)$ for verbs.

When affixed to nouns other than property nouns, the suffix -wəna is a marker of the prosecutive case and gives the meaning of route 'through, via' as in example 39. In addition, certain verbs govern the prosecutive case on their noun phrase complement. These are complements and objects of verbs connected to hunting, e.g. 'hunt', 'catch', 'gill', 'fish' or animal herding (see example 40), as well as verbs referring to speaking.

(39)

$\begin{array}{lll}\text { jaxa-wna } & \text { buksir } & \text { ḿina } \\ \text { river-Pros } & \text { tugboat } & \text { go.3sg }\end{array}$

(T65: 28)

'The tugboat sails along the river.'

(40) xal'a-wna wadrirya

fish-Pros gill.3sg

'He caught some fish'

(T65: 35)

When affixed to a property noun, it is used to produce adverbs of manner, as in example 41.

(41) tuku jal'a-m sawa-wna mada-doh

this day-ACC good-Pros spend-3PL $>$ SG

(T65: 214)

'They spent this day well.'

As noted in Section 4, property words cannot usually be inflected in case, unless they appear independently when referring to an actor or event rather than property. The use of the prosecutive suffix, however, is common, and it is the productive way of forming manner adverbs from property nouns.

For property verbs, adverbs of manner are expressed with the help an infinite converb form, the modal gerund, as illustrated in example 42. The modal gerund has the suffix $-\dot{s} \sim c$ for consonant stems and monosyllabic vowel stems and the suffix -əo for polysyllabic vowel stems (Salminen 1997: 114) which lengthens the stem vowel.

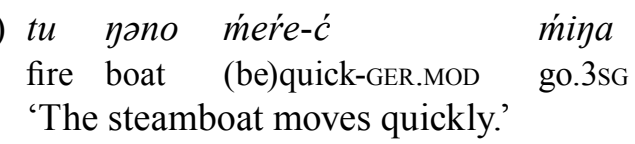

(T65: 252)

In addition to expressing manner, the modal gerund is used in predicates that consist of verb chains. When another verb in the predicate is finite, the other appears in the modal gerund form. Typical predicates consisting of two verbs with one as a modal 
gerund are phrasal predicates such as 'start' or 'stop' and also predicates with the modal verb tara- 'must' as illustrated in example 43.
(43) ńaxnta
kniga-mih
$\dot{m} i-\dot{c}$
tara
(NenTay2011)
to.him book-ACC.1sG.POSS give-GER.MOD need.3sG
'I have to give him my book.'

Adverbs of manner in Nenets are formed from property words using different strategies, the prosecutive suffix for property nouns and the converb form for property verbs. Both forms are used in functions other than expressions of manner with those other than property words. Thus, there is no grammatical distinction in the formation of adverbs of manner, and the division between property words and other verbs or nouns must be understood by semantic interpretation.

\section{Conclusion}

In carefully observing the morphological and syntactic behaviour of property concept words and searching for their differences compared to nouns and verbs in the same positions, it seems to be possible to find criteria to differentiate the categories of property concept words, or, adjectives, in almost any given language, also in Nenets. This study suggests that property words in Nenets, in both main word classes, can be distinguished from other members of the class, at least to some extent. Although at first glance, the distinguishing criteria seem to be mainly semantic, a closer examination shows that the semantics is also reflected in the structure. In Nenets, property words differ from other nouns and verbs on the basis of their syntactic behaviour in a noun phrase, as well as based on their derivational features. In addition, they are used in a comparative construction which, especially for nouns, can be considered syntactically distinguishing criteria, and they are used in the formation of adverbs of manner.

The core adjectival semantic types, dimension, age and value, and partly colour, are most commonly expressed with property nouns; as for others, adjectival semantics are expressed either with property nouns or property verbs. The comparison to other Samoyedic languages suggests that expressing property with nouns is a more archaic strategy than expressing property with stative verbs. Property verbs have probably developed in Nenets and some other Samoyedic languages due to the influence of non-Uralic Siberian language contact.

The fundamental question on if there are adjectives in Nenets or are not, or rather, if the property concept words described in this study should be labelled as two different classes of adjectives, I would eventually like to leave unanswered. Instead, I want to underline the fact that as there are no universal criteria for defining adjectives, and the existence and labelling of the categories depend on perspective, how and for whom it is described (e.g. for school grammars or typologists) always needs closer explanation. Nevertheless, both property nouns and property verbs in Nenets have 
some features typical to adjectives. However, since they share so many fundamental features of morphosyntactic behaviour with either nouns or verbs, they can formally be seen as subclasses of nouns and verbs.

Regardless, one unclear generalisation of Nenets presented in typological research can be clarified. In WALS, Nenets is labelled as a language in which "predicative adjectives have nonverbal encoding" on the basis of negation, where predicative verbs and adjectives show different constructions (Stassen 2011b). However, the negation different from predicate verbs applies naturally only to property nouns, as property verbs do not differ from other verbs in negation either. This is why the more justified strategy for Nenets is split encoding, in which case the set of property words is split into a subset with verbal encoding and a subset with nonverbal encoding.

Why not then label Nenets property words as an adjective class? The main reason is that there are two morphosyntactically different basic types of property concept words, and using one general term would only refer to semantic grouping, not revealing anything about the morphological and syntactic features of the words, and so, it is important to distinguish a grammatical class of adjectives from semantic grouping. However, because at least in some criteria, property concept words in both word classes can formally be distinguished from other nouns and verbs, it would be justified for the purposes of typology and contrastive as well as comparative linguistic studies, to label them as noun-like and verb-like adjectives that both form a subclass of the main word classes.

\section{List of abbreviations}

$\begin{array}{llll}\text { 1SG etc. } & \begin{array}{l}\text { person and number of } \\ \text { subject or possessor }\end{array} & \text { INF } & \text { infinitive } \\ \text { 1SG }>\text { SG etc. } & \text { person and number of subject } & \text { LOC } & \text { MOD } \\ & \begin{array}{l}\text { and number of object in } \\ \text { objective conjugation }\end{array} & \text { MODER } & \text { mood } \\ & \text { moderative (derivative suffix) } \\ \text { ablative } & \text { NEG } & \text { negative auxiliary } \\ \text { ABL } & \text { accusative } & \text { NOM } & \text { nominative } \\ \text { ACC } & \text { PART } & \text { partitive } \\ \text { COMP } & \text { comparative (derivative suffix) } & \text { POSS } & \text { possessive } \\ \text { CNG } & \text { dative } & \text { PRET } & \text { preterite (tense) } \\ \text { DAT } & \text { future (derivative tense) } & \text { PROS } & \text { prosecutive } \\ \text { FUT } & \text { PTCP } & \text { present participle } \\ \text { GEN } & \text { genetive } & \text { PTCP.PST } & \text { past participle } \\ \text { GER.MOD } & \text { modal gerund } & \text { REFL } & \text { reflexive conjugation }\end{array}$




\section{References}

Aikio, Ante 2006: New and old Samoyed etymologies (Part 2). - Finnisch-Ugrische Forschungen 59: 9-34.

Backhouse, Anthony E. 2004: Inflected and uninflected adjectives in Japanese. - Dixon \& Aikhenvald (ed.), Adjective classes: A cross-linguistic typology. Oxford: Oxford University Press.

Bartens, Raija 1981: Suomalais-ugrilaisen kantakielen muoto- ja lauserakenteesta. - Virittäjä 85: $101-108$.

Broschart 1997: Why Tongan does it differently: Categorial distinctions in a language without nouns and verbs. - Linguistic Typology 1:2: 123-166.

Castrén, Matias Aleksanteri 1854: Grammatik der samojedischen Sprachen. Herausgegeben von Anton Schiefner. St. Petersburg.

Chafe, Wallace 2012: Are adjectives universal? The case of Northern Iroquoia. - Linguistic Typology 16: 1-39

Compton, Richard J. 2012: The syntax and semantics of modification in Inuktitut: adjectives and adverbs in a polysynthetic language. Department of Linguistics, University of Toronto. <http://hdl.handle.net/1807/33968>. Accessed on 8.2.2013.

Croft, William 1991: Syntactic categories and grammatical relations: The Cognitive Organization of Information. Chicago: University of Chicago Press

Dixon R. M. W. 1977: Where have all the adjectives gone? - Studies in Language 1: 19-80.

Dixon R. M. W. 2004: Adjective classes in typological perspective. - R. M. W. Dixon \& Alexandra Y. Aikhenvald (eds), Adjective classes: A cross-linguistic typology. Oxford: Oxford University Press. 1-49.

Dixon R. M.W. 2010: Basic Linguistic Theory Volume 2: Grammatical Topics. Oxford: Oxford University Press.

Dryer, Matthew S. 2011: Order of Degree Word and Adjective. - Matthew S. Dryer \& Martin Haspelmath (eds), The World Atlas of Language Structures Online. Munich: Max Planck Digital Library, chapter 1. Available online at $<$ http://wals.info/chapter/1 $>$. Accessed on 8.2.2013.

Evans, Nicholas \& Toshiki Osada 2005: Mundari: The myth of a language without word classes. Linguistic Typology 9 (2005), 351-390.

Floyd, S. 2011: Re-discovering the Quechua adjectives. Linguistic Typology 15. 25-63.

Gil, David. 2011: Adjectives without Nouns. - Matthew S. Dryer \& Martin Haspelmath (eds), The World Atlas of Language Structures Online. Munich: Max Planck Digital Library, chapter 61. Available online at $<$ http://wals.info/chapter/61>. Accessed on 15.4.2013.

Hajdú, Péter 1968: Chrestomathia Samoiedica. Budapest: Tankönyvkiadó.

Hajek, John 2004: Adjective classes: What can we conclude? - R. M. W. Dixon \& Alexandra Y. Aikhenvald (eds), Adjective classes: A cross-linguistic typology. Oxford: Oxford University Press. 348-361.

Hamari, Arja 2007: The negation of stative relation clauses in the Mordvin languages. Memoires de la Societé Finno-Ougrienne 254. Helsinki: Suomalais-Ugrilainen Seura.

Haspelmath, Martin 2010: Comparative concepts and descriptive categories in cross-linguistic studies. Language vol 86, nro 3: 663-687

Hopper, Paul J., and Sandra A. Thompson. 1984. The Discourse Basis for Lexical Categories in Universal Grammar. - Language 60: 703-752. 
Jalava, Lotta 2012: Tempuksen ilmaiseminen tundranenetsin moduksissa. - Tiina Hyytiäinen, Lotta Jalava, Janne Saarikivi \& Erika Sandman (eds). Per Urales ad Orientem. Iter Polyphonicum Multilingue. Festskrift tillägnad Juha Janhunen på hans sextioårsdag den 12 februari 2012. 131-144. Mémoires de la Société Finno-Ougrienne 264. Helsinki: Suomalais-Ugrilainen Seura.

Janhunen, Juha 1977: Samojedischer Wortschatz. Gemeinsamojedische Etymologien. Castrenianumin toimitteita 17. Helsinki: Helsingin yliopisto, Castrenianum.

Janhunen, Juha 1998: Samoyedic. - Daniel Abondolo (ed.), The Uralic Languages. London \& New York: Routledge. 457-479.

Koivisto, Helinä 1987: Partisiippien adjektiivistuminen suomen kielessä. Suomalaisen Kirjallisuuden Seuran Toimituksia 474. Helsinki: Suomalaisen Kirjallisuuden Seura.

Maslova, Elena 2003: A Grammar of Kolyma Yukaghir. Berlin \& New York: Mouton de Gruyter.

McNally, Louise \& Christopher Kennedy 2008 (ed.): Adjectives and adverbs: syntax, semantics, and discourse. Oxford Studies in Theoretical Linguistics. Oxford: Oxford University Press.

Miestamo, Matti 2011: Symmetric and Asymmetric Standard Negation. - Matthew S. Dryer \& Martin Haspelmath (eds), The World Atlas of Language Structures Online. Munich: Max Planck Digital Library, chapter 113. Available online at $<$ http://wals.info/ chapter/113>. Accessed on 23.4.2013.

Nedjalkov, Igor 1997: Evenki. Descriptive grammars. London: Routledge.

Pajunen, Anneli 1994: Adjektiivikategorian universaaliudesta. - Virittäjä 98: 513-542.

Pajunen, Anneli 1998: Pääsanaluokkien eriytymättömyydestä uralilaiskielissä. - Anneli Pajunen (ed.), Kieliopillistumisesta, analogiasta ja typologiasta. Helsinki: Suomalaisen Kirjallisuuden Seura. 56-106.

Payne, Thomas E. 1997: Describing morpho-syntax: a guide for field linguistics. Cambridge: Cambridge University press.

Raun, Alo 1960: The equivalents of English "than" in Finno Ugric. - American Studies In Uralic Linguistics. Indiana University Publications, Uralic and Altaic Series, Vol. 1. Bloomington. 149-247.

Ravila, Paavo 1960: Adjektiiviattribuutin kongruenssin synty suomen kielessä. - Sananjalka 2: 28-35.

Ravila, Paavo 1957: Sanaluokat, erityisesti uralilaisia kieliä silmällä pitäen. - Virittäjä 57: 41-50.

Salminen, Tapani 1993: Word classes in Nenets (and a few words about their Uralic parallels). - Ulla-Maija Kulonen (ed.), Festschrift für Raija Bartens zum 25. 10. 1993. Mémoires de la Société Finno-Ougrienne 215. Helsinki: Suomalais-Ugrilainen Seura.

Salminen, Tapani 1997: Tundra Nenets inflection. Memoires de la Societé Finno-Ougrienne 227. Helsinki: Suomalais-Ugrilainen Seura.

Salminen, Tapani 1998: Nenets. - Daniel Abondolo (ed.) The Uralic languages. London: Routledge. 516-547.

Schachter Paul and Timothy Shopen 2007: Parts-of-speech systems. - Timothy Shopen (ed.), Language Typology and Syntactic Description. Second edition. Volume 1, Clause Structure. 1-60.

Siegl Florian 2013: Materials on Forest Enets, an Indigenous Language of Northern Siberia. Memoires de la Societé Finno-Ougrienne 267. Helsinki: Suomalais-Ugrilainen Seura. 
Stassen, Leon 1985: Comparison and universal grammar. Oxford: Basil Blackwell.

Stassen, Leon 2011a: Comparative Constructions. Consonant Inventories. - Matthew S. Dryer \& Martin Haspelmath (eds), The World Atlas of Language Structures Online. Munich: Max Planck Digital Library, chapter 1. Available online at $<$ http://wals.info/ chapter/1>. Accessed on 8.2.2013.

Stassen, Leon 2011b: Predicative Adjectives. - Dryer, Matthew S. \& Haspelmath, Martin (eds), The World Atlas of Language Structures Online. Munich: Max Planck Digital Library, chapter 118. Available online at $<$ http://wals.info/chapter/118 $>$. Accessed on 8.2.2013.

Tereščenko 1947 = Н. М. Терещенко: Очерк грамматики ненецкого (юрако-самоедского) языка. Ленинград: Учпедгиз.

Tereščenko 1956 = Н. М. Терещенко: Материалы и исследования по языку ненцев. Москва \& Ленинград: Издательство Академии Наук СССР.

Tereščenko 1965 = Н. М. Терещенко: Ненецко-русский словарь. Москва: Советская Энциклопедия.

Tereščenko 1968 = Н. М. Терещенко: К генезису частей речи (на материале самодийских языков). - Вопросы теории частей речи. На материале языков различных типов. Ленинград: Наука. 292-300.

Thompson, Sandra 1988: A Discourse Approach to the Cross-Linguistic Category 'Adjective'. - John Hawkins (ed.), Explaining Language Universals. Oxford: Basil Blackwell. $167-185$.

UEW = Rédei, Karoly 1988-1991: Uralisches etymologisches Wörterbuch I-III. Wiesbaden: Otto Harrassowitz.

Wagner-Nagy Beáta 2002 (ed.): Chrestomathia nganasanica. Studia uralo-altaica. Szeged \& Budapest: SZTE Finnugor tanszék, MTA Nyelvtudományi Intézet.

Wierzbicka, Anna 1986: What's in a noun? (or: How do nouns differ in meaning from adjectives? - Studies in Language 10 (2): 353-389.

VISK = Auli Hakulinen, Maria Vilkuna, Riitta Korhonen, Vesa Koivisto, Tarja Riitta Heinonen ja Irja Alho 2004: Iso suomen kielioppi. Helsinki: Suomalaisen Kirjallisuuden Seura. Verkkoversio, 20.1.2013. Available: <http://scripta.kotus.fi/visk>, URN:ISBN:978-952-5446-35-7. Accessed on 8.2.2013. 